\title{
Spatial Distribution and Self-Correlation of Mother and Child Health Indicators in the State of Parana, Brazil ${ }^{1}$
}

\author{
Emiliana Cristina Melo² \\ Thais Aidar de Freitas Mathias ${ }^{3}$
}

\begin{abstract}
Aiming to analyze the spatial distribution and self-correlation of data of mother-child health in Parana, Brazil, variables were selected from the Information System on Live Births, grouped into socioeconomic indicators: teenage mother, low education, high parity, race/color black of newborn; healthcare indicators: the prenatal coverage, prematurity and cesarean delivery and result indicators: low birth weight. The indicators were distributed in thematic maps and spatial self-correlation was measured using Moran's index that quantifies the degree of self-correlation. There was significant spatial self-correlation of teenage mother, low education and high parity of the "high-high" type in the macro-regions East, Campos Gerais and South; of low coverage of antenatal care in Campos Gerais, Central-south and North and of cesarean delivery in the Northwest. Elevated proportions of indicators of risk to the health of mother and child were found in the regions East, Campos Gerais and South. These results support the evaluation and planning of health services.
\end{abstract}

Descriptors: Residence Characteristics; Public Health Nursing; Maternal-Child Nursing; Ecological Studies; Epidemiology.

\footnotetext{
${ }^{1}$ Article extracted from Master's Dissertation "Nascimentos no Estado do Paraná: Análise de indicadores da saúde da mulher e da criança", presented to Programa de Pós-graduação em Enfermagem, Universidade Estadual de Maringá, PR, Brazil. Supported by Ministério da Saúde and the Conselho Nacional de Pesquisa e Desenvolvimento Tecnológico (CNPq Process \# 473395-2007-0).

${ }^{2}$ RN, M.Sc. in Nursing, Assistant Professor, Universidade Estadual do Norte do Paraná, PR, Brazil. E-mail: emiliana_melo@hotmail.com.

${ }^{3}$ RN, Ph.D. in Public Health, Adjunct Professor, Departamento de Enfermagem, Universidade Estadual de Maringá, PR, Brazil. E-mail: tafmahias@wnet.com.br.
}

Corresponding Author: Emiliana Cristina Melo Universidade Estadual do Norte do Paraná - Campus Luiz Meneghel Departamento de Enfermagem Rodovia BR-369 Km 54 Vila Maria, Caixa Postal 261 CEP: 86360-000 Bandeirantes, PR, Brasil E-mail: emiliana_melo@hotmail.com 


\title{
Distribuição e autocorrelação espacial de indicadores da saúde da mulher e da criança, no Estado do Paraná, Brasil
}

Com o objetivo de analisar a distribuição e autocorrelação espacial de dados de saúde materno-infantil, no Paraná, Brasil, foram selecionadas variáveis do Sistema de Informação de Nascidos Vivos, agrupadas em indicadores socioeconômicos: mãe adolescente, baixa escolaridade, alta paridade, recém-nascido de raça/cor negra; assistenciais: cobertura de pré-natal, prematuridade e parto cesáreo e resultante: baixo peso ao nascer. Os indicadores foram distribuídos em mapas temáticos e a autocorrelação espacial foi mensurada pelo índice de Moran, que quantifica o grau de autocorrelação. Houve autocorrelação espacial significativa de mãe adolescente, baixa escolaridade e alta paridade do tipo "alto-alto" nas macrorregionais Leste, Campos Gerais e Sul; de baixa cobertura pré-natal em Campos Gerais, Centro-sul e Norte e de parto cesáreo na Noroeste. Proporções elevadas de indicadores de risco à saúde da mulher e da criança foram evidenciadas nas regiões Leste, Campos Gerais e Sul. Esses resultados permitem a avaliação e o planejamento dos serviços de saúde.

Descritores: Distribuição Espacial da População; Enfermagem em Saúde Pública; Enfermagem Materno-Infantil; Estudos Ecológicos; Epidemiologia.

\section{Distribución y auto-correlación espacial de indicadores de la salud de la mujer y del niño en el estado de Paraná, Brasil}

\begin{abstract}
Con el objetivo de analizar la distribución y auto-correlación espacial de datos de salud materno-infantil en Paraná, Brasil, fueron seleccionadas variables del Sistema de Información de Nacidos Vivos, agrupadas en indicadores socioeconómicos: madreadolescente, baja escolaridad, alto número de hijos, recién nacido de raza/color negra; asistenciales: cobertura de prenatal, prematuridad y parto por cesárea y resultante: bajo peso al nacer. Los indicadores fueron distribuidos en mapas temáticos y la autocorrelación espacial fue medida por el índice de Moran que cuantifica el grado de autocorrelación. Hubo auto-correlación espacial significativa de madre adolescente, baja escolaridad y alto número de hijos del tipo "alto-alto" en las macro-regionales Este, Campos Gerais y Sur; de baja cobertura de prenatal en Campos Gerais, Centro-sur y Norte y de parto por cesárea en la Noroeste. Proporciones elevadas de indicadores de riesgo a la salud de la mujer y del niño se evidenciaron en las regiones Este, Campos Gerais y Sur. Este tipo de resultados permiten la evaluación y la planificación de los servicios de salud.
\end{abstract}

Descriptores: Distribución Espacial de la Población; Enfermería en Salud Pública; Enfermería Maternoinfantil; Estudios Ecológicos; Epidemiología.

\section{Introduction}

The health of mother and child remains a priority in the agenda of actions and programs of the Brazilian National Health System (SUS). Besides the traditional information on morbidity and mortality, other information can be used to describe and understand, even indirectly, the health aspects of mother and child and the health care in a particular location. Data such as age and education of the mother, type of delivery, birth weight and number of prenatal care visits should be constantly analyzed by the health team, as well as describing the health situation of the community, these data can provide important information on the activities 
developed, particularly within the scope of primary care in the municipalities. Many studies describe the health indicators of the mother and the newborn using the database of the Information System on Live Births (Sinasc), highlighting analysis of infant mortality ${ }^{(1)}$ low birth weight ${ }^{(2)}$ and occurrence of cesarean birth(3).

Sinasc, established in Brazil in 1990 by the Ministry of Health, uses as an instrument the Birth Certificate $(B C)$, an individualized and standardized document, with key data such as age and education of mother, birth data such as weight, Apgar score which allows the epidemiological profile of the health of the population to be established and specific rates to be calculated to support planning and policy making. One way to know the health in the community is through the analysis of indicators, according to geographical areas that identify clusters of municipalities or districts with similar characteristics, from the distribution of patterns of morbidity to the allocation of services(4).

Georeferencing, spatial distribution and the use of thematic maps in health constitute an important technique in the analysis of risks to collective health and offer great possibilities for researchers, becoming a powerful tool for the connection between health and geographic area(5), allowing the identification of variables that reveal the social, economic and environmental structure in which a health event occurs, for the decisive factors for the reproduction of social inequalities and consequently of health. The distribution analysis of indicators, according to geographical areas, is a powerful instrument in health research and can contribute to the understanding of the processes involved in a particular phenomenon that one wishes to study, making it possible to analyze characteristics and differences of each territorial space, beyond the simple geographic perspective, covering the socially constructed space ${ }^{(6)}$. Given the importance of knowing the reality of each municipality in relation to health and living conditions, especially in regard to maternal-infantile population, exploratory studies using epidemiological data and health indicators should be conducted.

Although Paraná presents, in general, better socioeconomic and health indicators than the average of Brazil(7), there are no studies that analyze the distribution and behavior of these indicators in the geographic space of the state. Therefore, this study sought to ascertain whether the spatial distribution of the variables, contained in the database Sinasc, identifies clusters of municipalities or homogeneous areas of risk in Paraná State and, thus, provides support for the planning and distribution of resources and health programs in the macro-social scope. The aim of this study was to analyze the spatial distribution and autocorrelation of the Sinasc, socioeconomic and health of mother and child data in the State of Parana in 2007.

\section{Materials and Method}

This was an exploratory ecological study with all live births in the State of Paraná in 2007. Data were collected from the database Sinasc, provided by the State Secretariat of Health of Paraná (SESA). In total 147,207 live births to mothers living in 399 cities in the state were georeferenced, excluding 1,802 with unknown or unreported variables ( $1.22 \%$ of total births). For the analysis, the municipalities were grouped into six macroregions: East (Curitiba), Campos Gerais (Ponta Grossa), North (Londrina), Northwest (Maringá), West (Cascavel) and Centre-south (Guarapuava) (Figure 1). The macroregions, although they do not constitute administrative areas, aim to articulate the regions of health so they can join forces together to solve common problems ${ }^{(8)}$.

The socioeconomic indicators georeferenced were: teenage mother ( $<20$ years of age), low education ( $<8$ years), high parity ( $>3$ children born in previous pregnancies), new born of race/color black (race/ color black and mixed). These data were considered in this category because they indirectly indicate the socioeconomic situation of the population, and influence the conditions of prenatal and birth care.

Healthcare indicators of Sinasc that allow the verification of possible fragilities of the health care to pregnant women were considered: low prenatal coverage ( $<7$ prenatal visits); prematurity $(<37$ weeks gestation) and cesarean delivery. Low birth weight $(<2,500 \mathrm{~g})$ was considered a result indicator. The analysis, according to geographical area, allows the observation of the variation in occurrence in the municipalities and helps in the comprehension of the quality of care provided to pregnant women during the prenatal. The proportions of each indicator, standardized into quartiles, were distributed in thematic maps, conforming to the maximum and minimum value in scales of gray, with lighter shades for the lower values and darker for higher values. 
For spatial autocorrelation the global Moran's (I) and local Moran's (LISA) indexes were used as statistical tools. Spatial autocorrelation measures the relationship between observations with spatial proximity, considering that spatially close observations have similar values ${ }^{(9)}$. The global indicators of spatial autocorrelation (Moran's I) provide a single measure for the set of all municipalities characterizing the entire region of study.

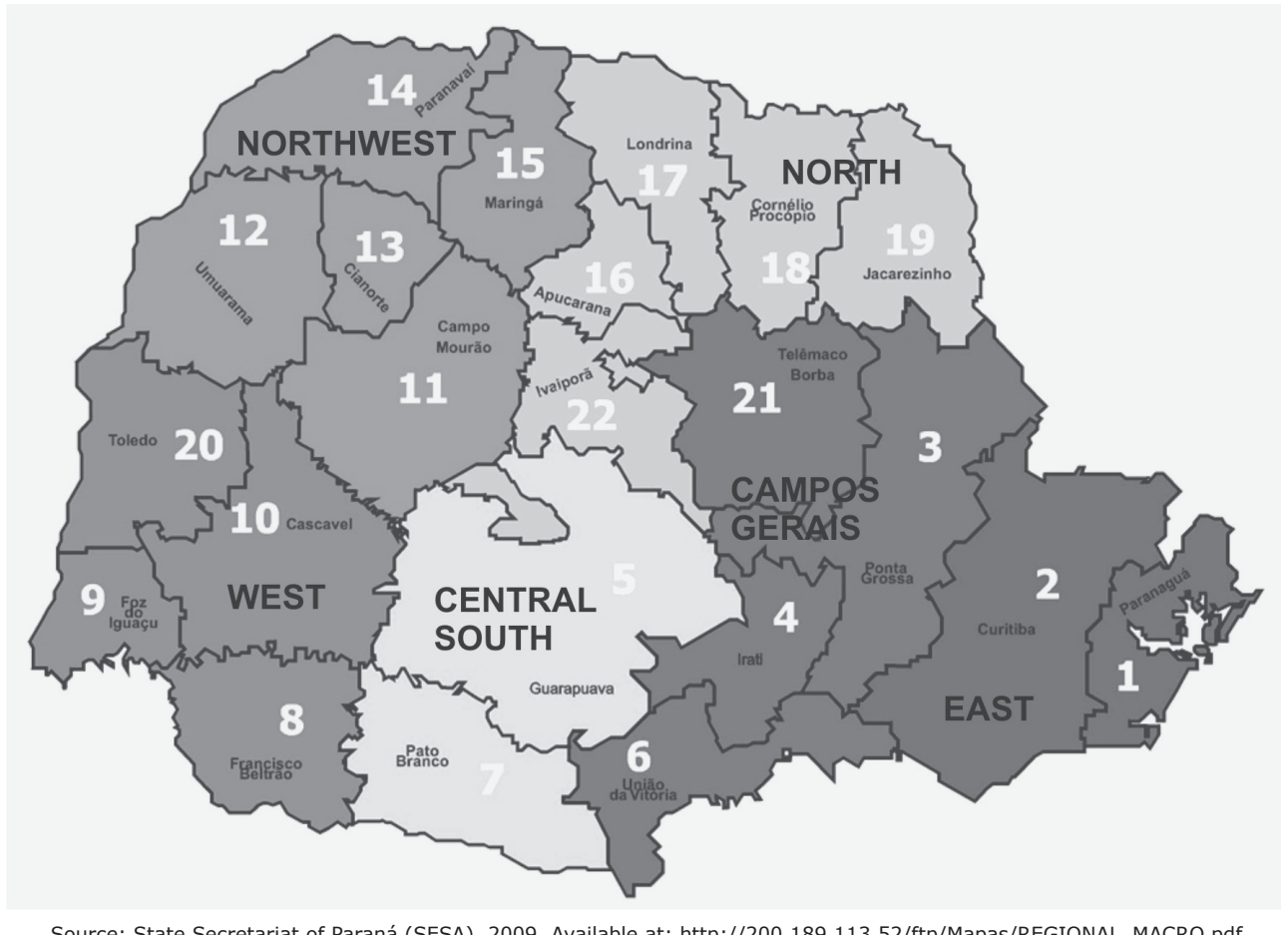

Figure 1 - Map of Paraná state, showing macro-regions and health regions

The distribution patterns of indicators were examined on a smaller scale through the local Moran's (LISA) index, producing a specific value for each municipality, allowing the visualization of clusters of municipalities with similar values for the selected indicators. Correlations of the type "high-high" show municipalities with high proportions of the indicator surrounded by other municipalities also with high proportions of the same indicator; "low-low" municipalities with low proportions surrounded by municipalities with low proportions of the same indicator; "high-low" municipalities with high proportions surrounded by municipalities with low proportions of this indicator and "low-high" municipalities with low proportions surrounded by municipalities with high proportions of the same indicator. The analyses considered the significance level $p<0.05$ and the cartographic products were developed using the software ESRI ArcGIS 9.2 and TerraView 3.3. The research project was approved by the Standing Committee on Ethics in Research Involving Human Beings of Maringá State University, Protocol No. 703/2008.

\section{Results}

The proportion of teenage mothers ranged from $5 \%$ to $39 \%$ and the proportion of low maternal education from $8.3 \%$ to $86.6 \%$. The highest values for both indicators were focused in the macro-regions Campos Gerais (Ponta Grossa), Centre-south (Guarapuava) and East (Curitiba). These same macro-regions concentrated the highest proportions of mothers with high parity, with some municipalities showing percentage between $11 \%$ and $21.6 \%$. Higher rates of race/color black were found in the macro-regions Northwest (Maringá), North (Londrina) and a small part of Campos Gerais (Ponta Grossa), where proportions of $7 \%$ to $18 \%$ prevailed (Figure 2 ). 

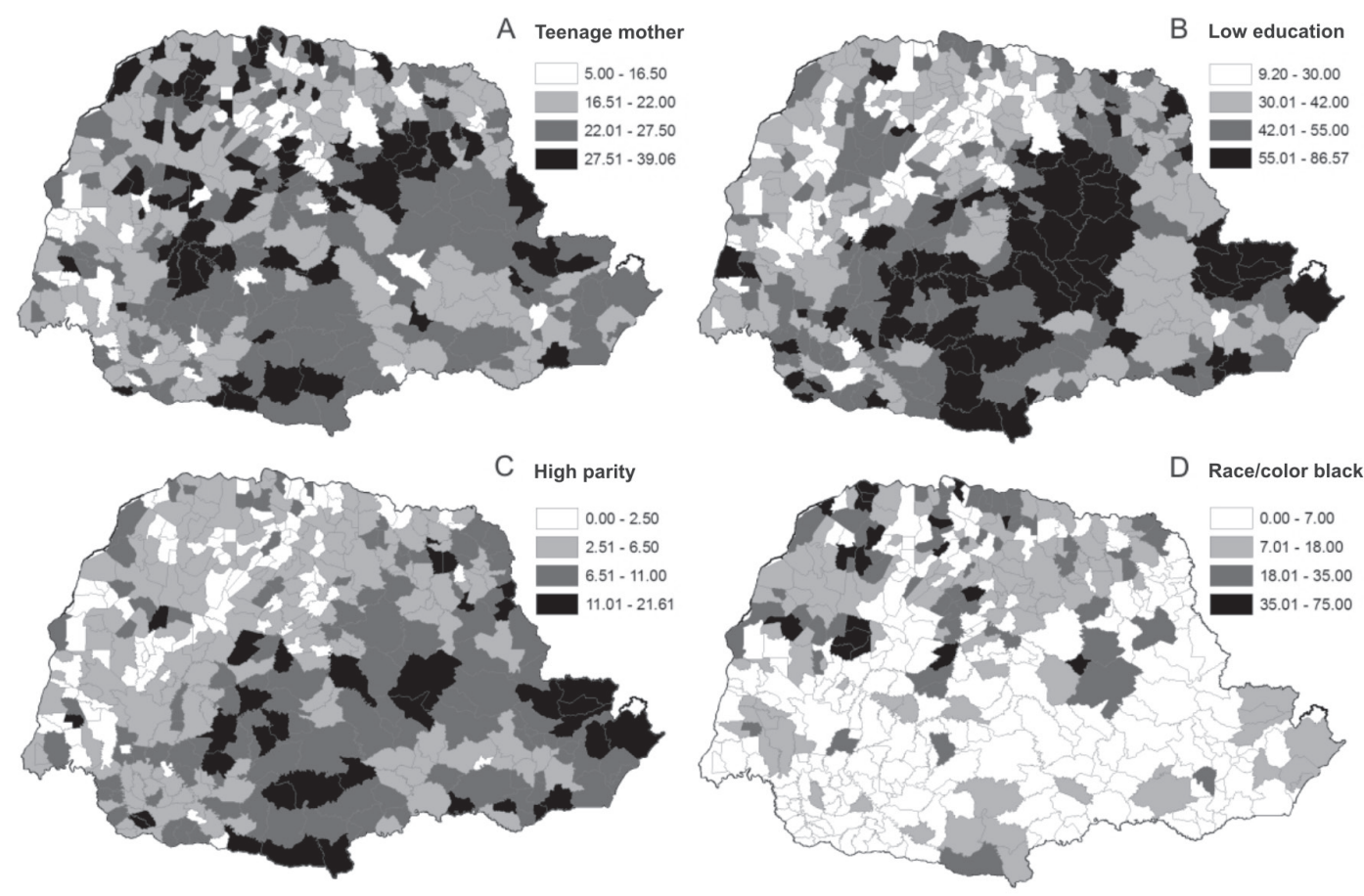

Figure 2 - Spatial distribution of socioeconomic indicators, Paraná, 2007. (A) Percentage of teenage mothers. (B) Percentage of mothers with low education. (C) Percentage of mothers with high parity. (D) Percentage of live births of race/color black

Higher proportions of low prenatal coverage of were found in part of the macro-region North (Londrina) and the upper portion of the Campos Gerais (Ponta Grossa), Centre-south (Guarapuava) and East (Curitiba) (Figure 3). High proportions of cesarean delivery were observed in the macro-regions Northwest (Maringá),
West (Cascavel) and in the upper portion of the region North (Londrina) in municipalities with percentages of up to $95 \%$. Most municipalities of Paraná State showed percentages of prematurity between $4 \%$ and $9 \%$ and low birth weight between $6 \%$ and $11 \%$ (Figure 3 ).
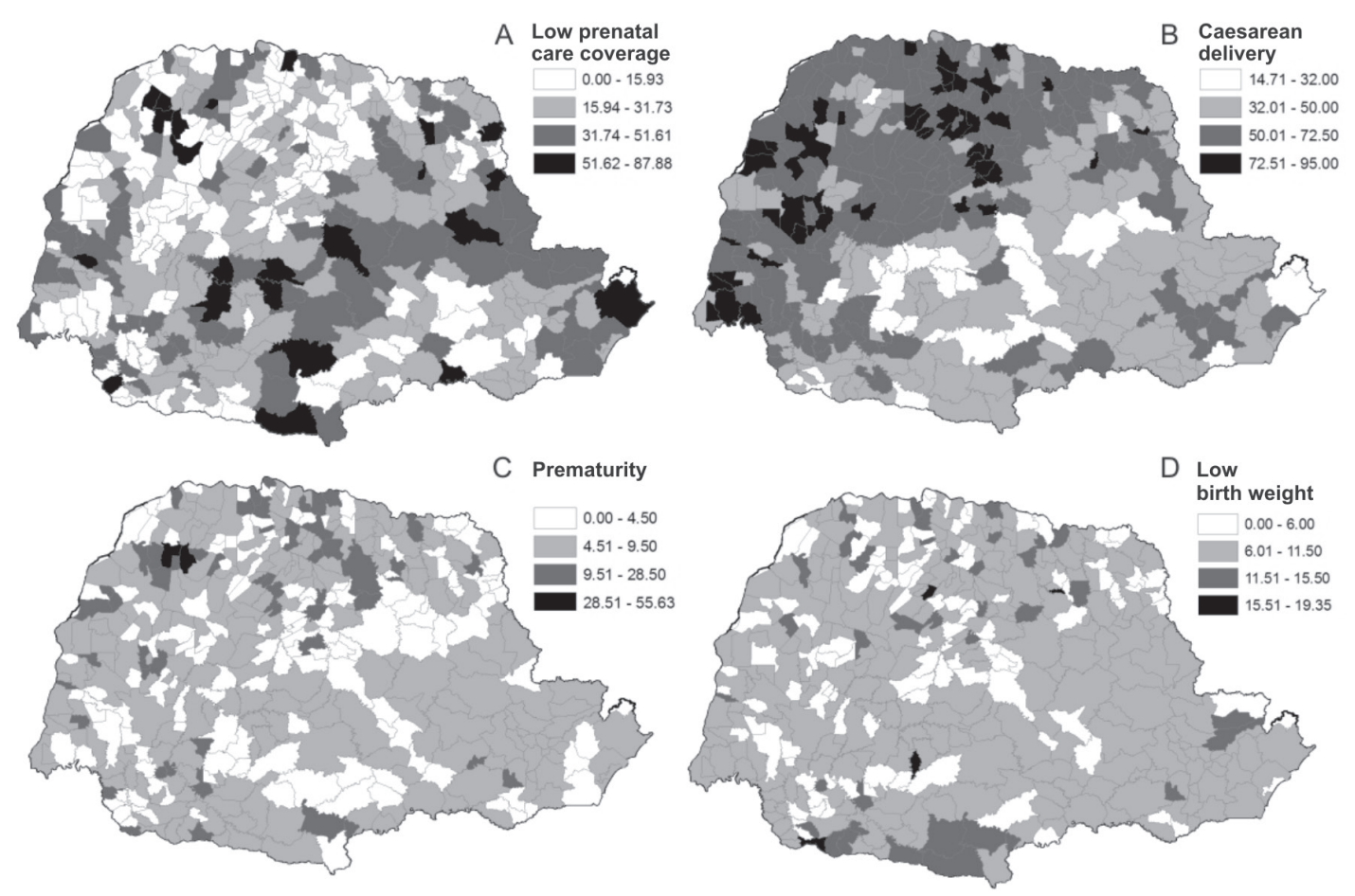

Figure 3 - Spatial distribution of health care and result indicators, Paraná 2007. (A) Percentage of mothers with low prenatal care coverage. (B) Percentage of Caesarean delivery. (C) Percentage of premature births. (D) Percentage of low birth weight 
With the exception of low birth weight, all indicators showed significant overall self-correlation indicating the presence of positive global spatial dependence among the municipalities (data not shown).

Figures 4 and 5 show the results of the analysis of local spatial self-correlation(Moran Lisa), highlighting the socioeconomic indicators low education and high parity with similar results, i.e. "high-high" self-correlation throughout the macro-regions Campos Gerais (Ponta Grossa), Centre-south (Guarapuava) and a small portion of the macro-region East (Curitiba), and "lowlow" correlation in the macro-regions North (Londrina) and Northwest (Maringá). For the healthcare indicators, there were correlations of the type "high-high" in the macro-regions Campos Gerais (Ponta Grossa), Centresouth (Guarapuava) and North (Londrina). For cesarean delivery, the "low-low" correlations were significant in the overall region of the state, especially in the macroregions Centre-south (Guarapuava) and Campos Gerais (Ponta Grossa).
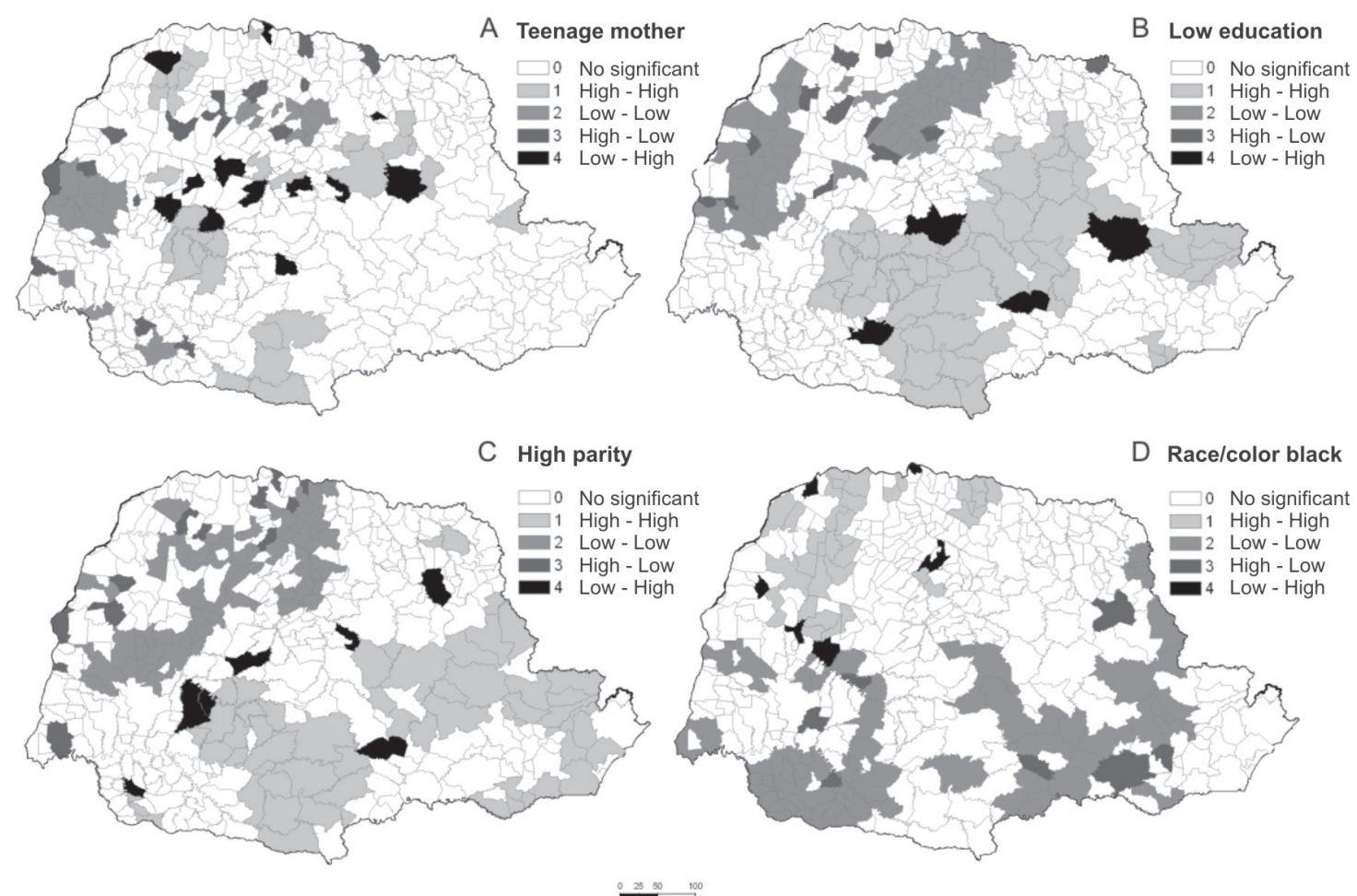

Figure 4 - Moran Local Index showing socioeconomic indicators, Paraná, 2007. (A) Percentage of teenage mothers. (B) Percentage of mothers with low education. (C) Percentage of mothers with high parity. (D) Percentage of live births of race/color black

\section{Discussion}

The results of this study show the difference between the regions of Paraná State for indicators of socioeconomic situation, teenage mother, low maternal education and high parity indicating clusters of municipalities with higher proportions in the macroregions Centre-south (Guarapuava), East (Curitiba) and Campos Gerais (Ponta Grossa). 


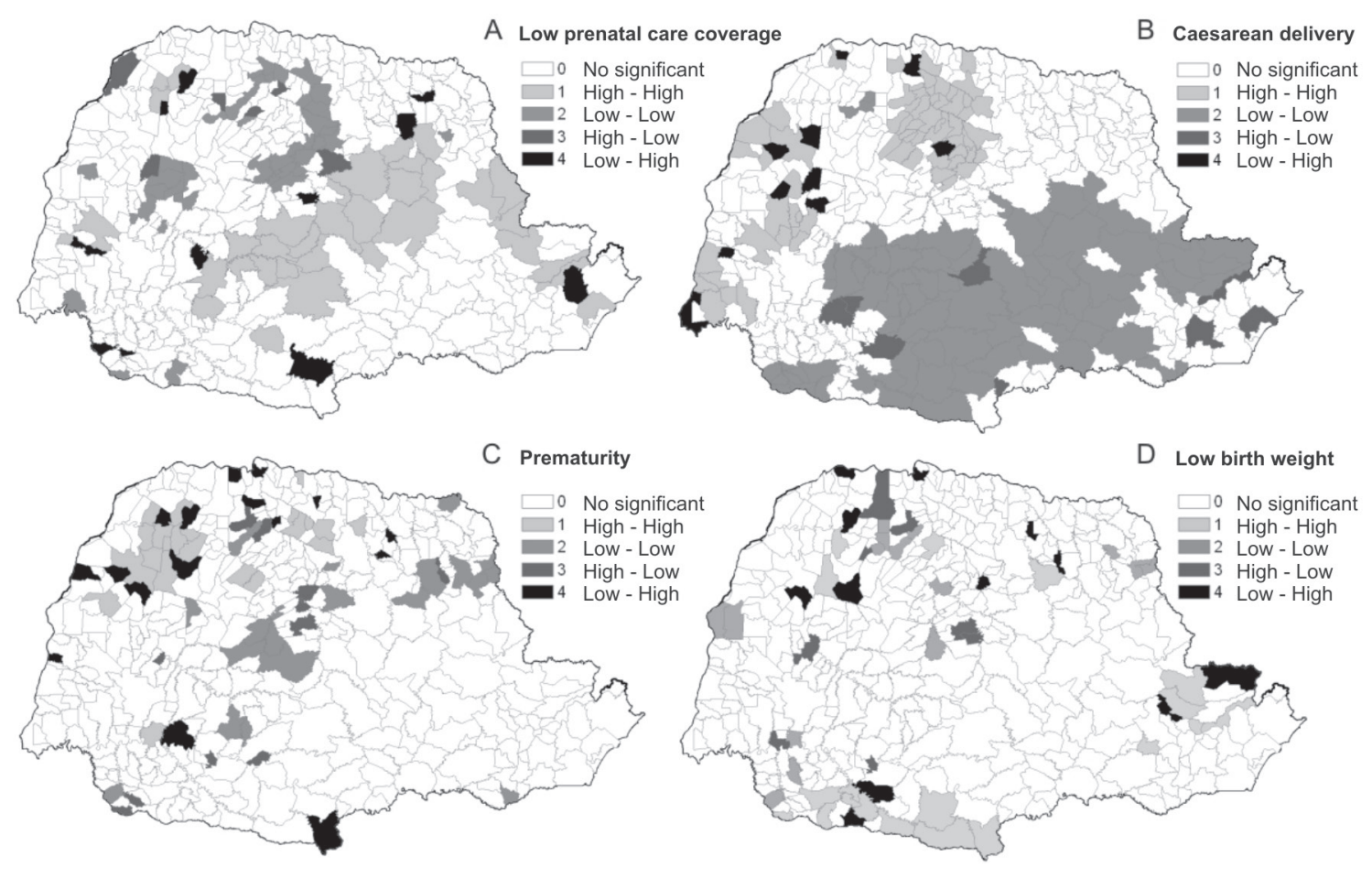

${ }^{0.250}=100$

Figure 5 - Moran Local Index showing health care and result indicators, Paraná 2007. (A) Percentage of low prenatal care coverage. (B) Percentage of Caesarean delivery. (C) Percentage of premature births (D) Percentage of low birth weight

One probable explanation for the concentration of teenage mothers, with low education and high parity in the same regions of the State may be the result of the characteristics of those regions where municipalities with a low, medium-low, or medium level of socioeconomic development predominate ${ }^{(10)}$. This distribution is confirmed by the self-correlation analysis, which was positive for the type "high-high", i.e. municipalities with high proportions bordering municipalities that also have high proportions of these indicators. This finding is similar to results encountered by other researchers that associate the high incidence of teenage mothers, mothers with low education and mothers with high parity to populations with social and economic disadvantages. That is, teenage mothers with lower purchasing power tend, not only to have multiple and early pregnancies, but also noncontinuity of study, decreasing the likelihood of entering the labor market and determining the maintenance of the cycle of poverty ${ }^{(11-12)}$. Analysis performed in Rio de Janeiro is also in agreement with the results of this study, where there was variation in the distribution of teenage mothers and significant self-correlation with clusters of areas with high proportions of teenage mothers in areas close to slums, demonstrating the association of this indicator with low socioeconomic conditions ${ }^{(13)}$.
Regarding race/color black, a large extension with a low percentage (from $0 \%$ to $7 \%$ ) in the Paraná territory was observed, specifically in the macroregions Center South (Guarapuava), West (Cascavel), East (Curitiba) and Campos Gerais (Ponta Grossa). Higher percentages (of $7.1 \%$ to $75 \%$ ) were found in the macro-regions North (Londrina) and Northwest (Maringá) which cover the municipalities of medium, medium-high and high socioeconomic development ${ }^{(10)}$. Historically, race/color black has been associated with low socioeconomic conditions, with higher proportions prevailing in areas considered vulnerable to poverty(14), perpetuating social discrimination that is reflected in other indicators, such as the percentage of pregnancy and birth complications and infant mortality, which are substantially higher among the black population compared to other categories of race/color(15). The fact that, in Parana State, the highest proportions of this indicator were focused in clusters of municipalities with the best socioeconomic conditions indicates the need for specific studies and studies in urban areas. The way to observe the distribution of social and health indicators adopted in this study does not identify situations that occur within the municipalities such as the standard of the residences, infrastructure, sanitation, education and 
health services, childcare, and especially the occupation of residents in professional categories that also define unequal situations ${ }^{(16)}$.

The cesarean delivery healthcare indicator in this study, is the obstetric procedure that should be used instead of vaginal delivery in situations of risk to the mother or baby and has been associated with better socioeconomic conditions ${ }^{(7,17)}$. This finding seems to agree with the results of this study, since the higher proportions were focused in macro-regions of better socioeconomic development of Paraná State(10). Other studies have associated the high incidence of caesarean delivery to rising socioeconomics of the populations, with an increased propensity of normal delivery in adolescents, with low educational levels and, probably, lower conditions for discussion with the obstetrician and for payment of the surgical delivery(11-12). The practice of cesarean delivery has been recurrent and is not always treated as an option that meets the real needs of pregnant women, but, especially for the professionals involved, as time management, duration and moment of performance of delivery; the association of cesarean delivery with tubal ligation; the unpreparedness of the professional to carry out normal deliveries, and also the possibility of greater financial gains ${ }^{(18)}$.

It was observed that percentages of low coverage of prenatal care were concentrated in regions with lower socioeconomic indicators and lower levels of development, such as the macro-region Centre-south (Guarapuava) and part of the macro-region Campos Gerais (Ponta Grossa) and East (Curitiba)(10). Studies highlight that municipalities with higher proportions of women who undergo fewer prenatal visits are those with the highest percentage of teenage mothers, with lower education levels, and with greater numbers of children, demonstrating that in regions with worse socioeconomic conditions there are difficulties in offering quantity and quality health care for their residents(19-20).

Special attention should be given to the macroregion Centre-south (Guarapuava) that showed clusters of municipalities with more than $50 \%$ of mothers with low prenatal coverage, exposing these pregnant women and their children to greater risk of morbimortality. An inverse spatial distribution was observed of high percentages of caesarean delivery and low prenatal coverage, demonstrating distinct characteristics of the municipalities of Paraná in relation to the two variables considered healthcare indicators.

The distribution of the low birth weight result indicator, contrary to the socioeconomic and healthcare indicators, did not show visually identifiable spatial patterns. The percentages of low birth weight, even without significant spatial self-correlation, were between $11.5 \%$ and $15.5 \%$ in clusters of municipalities of the South of the State, between the macro-regions Centre-south (Guarapuava) and Campos Gerais (Ponta Grossa), in the municipalities of Flor da Serra do Sul, in the macro-region West, Virmond in the macro-region Central-south, Floresta in the macro-region Northwest and Novo Santa Barbara in the macro-region North, all with percentages greater than $15.1 \%$ of newborns with low weight, proportions much higher when compared to the means of Paraná and of Brazil which were $8.6 \%$ and $8.2 \%$ in 2007 , respectively ${ }^{(21)}$. Low birth weight exposes newborns to higher risks of newborn and infant morbimortality, and is a parameter used to evaluate the socioeconomic development and healthcare of the region studied. Lower proportions of this indicator are related to both improved quality of life and health of the population ${ }^{(11,22)}$. In a study performed in Rio de Janeiro, distribution of low birth weight similar to a mosaic was also found, with no pattern of significant spatial autocorrelation being encountered, which could represent limitation in the use of low birth weight as an indicator of risk areas ${ }^{(23)}$. It is important that further analysis be conducted using smaller geographic scales such as a single Health Region, municipality or even a neighborhood within the municipality.

This study may contribute to the scientific knowledge already published in this journal, which, despite using different approaches such as the spatial distribution of leprosy $\operatorname{cases}^{(24)}$ and the spatial distribution of

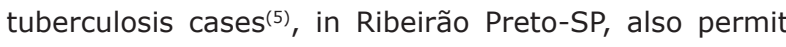
the visualization of the epidemiological patterns of events and processes of health, recognizing the factors that determine and facilitate decision-making about possible public health actions.

\section{Final considerations}

From the spatial distribution and self-correlation analysis it was possible to identify three clusters of municipalities, the macro-regions East (Curitiba), Campos Gerais (Ponta Grossa) and Centre-south (Guarapuava), which concentrated the highest proportions of risk indicators for the mother and her baby, where the pattern of distribution of percentages, visually identifiable in the space, establish a relationship with socioeconomic characteristics, enabling the observation of social differences and differences in 
access to and health services, which should constitute the focus of intervention, of social policies and of health in the State of Parana.

It is important to note the limitations of studies that use secondary data, in this case, provided by Sinasc, because there may be underreporting of births, specifically in the small municipalities, the existence of blank and ignored variables, or even errors and difficulties in filling in the variables in the $\mathrm{BC}$, such as the race/color of the newborn that is reported by the mother or observed by the professional who completes the $\mathrm{BC}$, or situations of birth weight and of the Apgar score incompatible with the weeks of gestation.

However, although there are limitations, the exploration of the data of Sinasc through the spatial distribution of health indicators of the mother and child in Paraná, showed areas of clusters of municipalities with high percentages of unfavorable population health indicators. This diagnosis can support epidemiological surveillance in the monitoring of vital statistics, in the planning and distribution of resources and health programs at the macro-social level, reinforcing the precepts of the Brazilian National Health System (SUS) in the decentralization of actions and public policies, facilitating surveillance for equity in health.

\section{Acknowledgments}

The authors acknowledge Professor Ricardo Nonakz, of the Department of Statistics, Universidade Estadual de Maringá, for the statistical support in the study.

\section{References}

1. Monteiro RA, Schmitz BAS. Infant mortality in the Federal District, Brazil: time trend and socioeconomic inequalities. Cad Saúde Pública. [internet]. 2007 [acesso: 17 mai 2008]; 23 (4): 767-74. Disponível em: http://www.scielo.br/pdf/csp/ v23n4/03.pdf

2. Uchimura TT, Pelissari DM, Soares DFPP, Uchimura NS, Santana, GS, Moraes, CMS. Fatores de risco para o baixo peso ao nascer segundo as variáveis da mãe e do recém-nascido, em Maringá - PR, no período de 1996 a 2002. Cienc Cuidado Saúde. 2007; 6(1):51-8.

3. Villar J, Valladares E, Wojdyla D, Zavaleta N, Carroli G, Velazco $A$, et al. [Caesarean delivery rates and pregnancy outcomes: the 2005 WHO global survey on maternal and perinatal health in Latin America]. Science Direct. [internet]. 2006 [acesso: 9 jul 2008]; 367(9525):1819-29. Disponível em: http://www. collegeofmidwives.org/Citations\%20or\%20text\%2002/CSSVD_compareOutcomes_Lancet_2006.pdf

4. Carvalho MS, Souza-Santos R. Análise de dados espaciais em saúde pública: métodos, problemas, perspectivas. Cad Saúde Pública. [internet]. 2005 [acesso: 23 jul 2009]; 21 (2):361-78. Disponível em: http://www.scielo.br/pdf/csp/v21n2/03.pdf 5. Hino P, Villaz TCS, Sassaki CM, Nogueira JA, Santos CB . Geoprocessamento aplicado à área da saúde=Geoprocessing in health area $=$ Geoprocesamiento aplicado en el área de salud. Rev Latino-am. Enfermagem. [internet]. novembro-dezembro 2006 [acesso: 23 jan 2010]; 14(6):939-43. Disponível em: http:// www.scielo.br/scielo.php?script=sci_issuetoc\&pid $=0104116920$ 060006\&lng=pt\&nrm=iso. Português, Inglês, Espanhol.

6. Ricketts СT. Geographic information systems and public health. Annu. Rev. Public. Health. [internet]. 2003 [acesso: 25 mai 2010]; 24: 1-6. Disponível em: http://www.geo.hunter. cuny.edu/ dgreimer/TEMPALSKI/Ricketts\%20AnnRevPH\%20 2003.pdf

7. Soares NMV. Desigualdades na saúde reprodutiva das mulheres no Paraná. Rev Bras Epidemiol. [internet]. 2007 [acesso: 07 nov 2008]; 10(3):293-309. Disponível em: http://www.scielo.br/ pdf/rbepid/v10n3/01.pdf
8. Secretaria de Estado da Saúde do Paraná (BR). Plano estadual de saúde. 1997. [acesso: 15 set 2009]. Disponível em: http:// www.saude.pr.gov.br/RS/index.html

9. Nascimento LFC, Batista GT, Dias NW, Catelani CS, Becker D, Rodrigues L. Análise espacial da mortalidade neonatal no Vale do Paraíba, 1999 a 2001. Rev Saúde Pública. [internet]. 2007 [acesso: 15 jul 2009]; 41(1):94-100. Disponível em: http:// www.scielosp.org/pdf/rsp/v41n1/14.pdf

10. Instituto Paranaense de Desenvolvimento Econômico e Social (IPARDES). Tipologia dos municípios paranaenses segundo indicadores socioeconômicos e demográficos. 2003. [acesso: 20 mai 2009]. Disponível em: http://www.ipardes.gov. br/biblioteca/docs/tipologia.pdf

11. Conde-Agudelo A, Bélizan JM, Diaz-Rossello JL. [Epidemiology of fetal death in Latin América]. Acta Obstet Gynecol Scand. 2000; 79(3):371-8.

12. Barros FC, Victora CG, Barros AJD, Santos IS, Albernaz $E$, Matijasevich $A$, et al. The challenge of reducing neonatal mortality in middle-income countries: findings from three Brazilian birth cohorts in 1982, 1993, and 2004. Lancet. 2005; 365(3):847-54.

13. Friche AAL, Caiaffa WT, César CC, Goulart LMF, Almeida MCM. Indicadores de Saúde materno infantil em Belo Horizonte, Minas Gerais, Brasil, 2001: análise dos diferenciais intra-urbanos. Cad Saúde Pública. [internet]. 2006 [acesso: 19 mai 2008]; 22(9):1995-65. Disponível em: http://www.scielosp.org/pdf/ $\mathrm{csp} / \mathrm{v} 22 \mathrm{n} 9 / 20 . \mathrm{pdf}$

14. Hearst MO, Oakes MJ, Johnson JP. The effect of racial residential segregation on black infant mortality. Am J Epidemiol [internet]. 2009 [acesso: 25 ago 2009]; 168(11):1247-54. Disponível em: http://aje.oxfordjournals.org/cgi/reprint/168/11/1247

15. Cardoso AM, Santos RV, Coimbra CEA Jr. Mortalidade infantil segundo raça/cor no Brasil: o que dizem os sistemas nacionais de informação? Cad Saúde Pública. [internet]. 2005 [acesso: 21 set 2009]; 21(5):1602-8. Disponível em: http://www.scielosp. org/scielo.php?script=sci_arttext\&pid=S0034 
16. Maricato E. Metrópole, legislação e desigualdade. Estud Av [internet]. 2003 [acesso: 23 out 2009]; 17:161-6. Disponível em: http://www.scielo.br/pdf/ea/v17n48/v17n48a13.pdf

17. Carniel EF, Zanolli ML, Antônio MARGM, Morcillo AM. Determinantes do baixo peso ao nascer a partir das Declarações de Nascidos Vivos. Rev Bras Epidemiol. 2008; 11(362):169-79. 18. Diniz CSG. Humanização da assistência ao parto no Brasil; os muitos sentidos de um movimento. Ciênc. saúde coletiva. [internet]. 2005 [acesso: 26 mai 2010]; 10(3):627-37. Disponível em: http://www.scielo.br/pdf/csc/v10n3/a19v10n3.pdf

19. Kogan MD, Alexander GR, Mor JM, Kieffer EC. Ethnic-specific preditors of prenatal care utilisation in Hawaii. Paediatr Perinat Epidemiol. 1998; 12 Suppl:152-62.

20. Coimbra LC, Silva AM, Mochel EG, Alves MTSSB, Ribeiro VS, Aragão VMF, et al. Fatores associados à inadequação do uso da assistência pré-natal. Rev Saúde Pública. [internet]. 2003 [acesso: 25 set 2009]; 37(4):456-62. Disponível em: http:// www.scielosp.org/pdf/rsp/v37n4/16780.pdf

21. Ministério da Saúde (BR). Base de dados do Sistema Único de Saúde (Datasus). Informações de Saúde. Estatísticas Vitais. Nascidos vivos [internet]: Brasília: Ministério da Saúde. 2007. [acesso: 14 jun 2008]. Disponível em: http://w3.datasus.gov. br/datasus/datasus.php
22. Gurgel RQ, Dias JMO, França VLA, Castañeda DFN. Distribuição espacial do baixo peso ao nascer em Sergipe, Brasil, 1995/1998. Cad Saúde Pública. [internet]. 2005 [acesso: 16 set 2009]; 21(5):1329-7. Disponível em: http://www.scielo.br/pdf/ csp/v21n5/04.pdf

23. D'Orsi E, Carvalho MS. Perfil de nascimentos no Município do Rio de Janeiro: uma análise espacial. Cad Saúde Pública. [internet]. 1998 [acesso: 13 dez 2008]; 14(2): 367-79. Disponível em: http://www.scielosp.org/pdf/csp/v14n2/0114.pdf

24. Gauy J S, Hino P, Santos C B. Distribuição espacial dos casos de hanseníase no município de Ribeirão Preto no ano de 2004=Spatial distribution of leprosy cases in Ribeirão Preto, Brazil, 2004=Distribución espacial de casos de hanseniasis en el municipio de Ribeirão Preto para el año 2004. Rev. LatinoAm. Enfermagem [internet]. junho 2007 [acesso: 24 mai 2010];15(3): 460-5. Disponível em: http://www.scielo.br/pdf/ rlae/v15n3/pt_v15n3a15.pdf. Português, Inglês, Espanhol. 